\title{
DIGITALCOMMONS
}

@WAYNESTATE-

Wayne State University

March 2020

\section{Impact of treatment modality on overall survival in localized ductal prostate adenocarcinoma: A National Cancer Database analysis}

\author{
Chandler Bronkema \\ chandler.bronkema2@med.wayne.edu \\ Sohrab Arora \\ Nikola Rakic \\ Akshay Sood \\ Deepansh Dalela
}

See next page for additional authors

Follow this and additional works at: https://digitalcommons.wayne.edu/som_srs

Part of the Male Urogenital Diseases Commons, Neoplasms Commons, Surgical Procedures, Operative Commons, and the Therapeutics Commons

\section{Recommended Citation}

Bronkema, Chandler; Arora, Sohrab; Rakic, Nikola; Sood, Akshay; Dalela, Deepansh; Keeley, Jacob; Jamil, Marcus; Peabody, James O.; Rogers, Craig G.; Menon, Mani; and Abdollah, Firas, "Impact of treatment modality on overall survival in localized ductal prostate adenocarcinoma: A National Cancer Database analysis" (2020). Medical Student Research Symposium. 17.

https://digitalcommons.wayne.edu/som_srs/17

This Research Abstract is brought to you for free and open access by the School of Medicine at DigitalCommons@WayneState. It has been accepted for inclusion in Medical Student Research Symposium by an authorized administrator of DigitalCommons@WayneState. 


\section{Authors}

Chandler Bronkema, Sohrab Arora, Nikola Rakic, Akshay Sood, Deepansh Dalela, Jacob Keeley, Marcus Jamil, James O. Peabody, Craig G. Rogers, Mani Menon, and Firas Abdollah 


\title{
Impact of treatment modality on overall survival in localized ductal prostate adenocarcinoma: A National Cancer Database analysis
}

\author{
Chandler Bronkema ${ }^{\mathrm{a}, \mathrm{b}}$, Sohrab Arora ${ }^{\mathrm{b}}$, Nikola Rakic ${ }^{\mathrm{a}, \mathrm{b}}$, Akshay Sood ${ }^{\mathrm{b}}$, Deepansh Dalela ${ }^{\mathrm{b}}$, Jacob \\ Keeley $^{\mathrm{b}}$, Marcus Jamil ${ }^{\mathrm{b}}$, James O. Peabody ${ }^{\mathrm{b}}$, Craig G. Rogers ${ }^{\mathrm{b}}$, Mani Menon ${ }^{\mathrm{b}}$, Firas Abdollah ${ }^{\mathrm{b}}$ \\ ${ }^{a}$ Wayne State University School of Medicine, Detroit, MI \\ ${ }^{\mathrm{b}}$ Vattikuti Urology Institute, Henry Ford Hospital, Detroit, MI
}

Key Words: Prostatic neoplasms; survival; National Cancer Database; histology; rare variants

INTRODUCTION AND OBJECTIVE: Ductal adenocarcinoma is considered a rare histological variant of prostate adenocarcinoma (PCa). Given the rarity of this subtype, optimal treatment strategies for men with nonmetastatic ductal PCa is largely unknown. We aimed to describe the impact of surgery, radiotherapy, and systemic therapy on overall survival (OS) in men with nonmetastatic ductal PCa.

METHODS: We retrospectively selected 2209 cases of ductal PCa, diagnosed between 2004 and 2015, within the National Cancer Database (NCDB). Exclusion of metastatic patients yielded a total sample of 1993 individuals. Cox regression analysis tested the impact of treatment (surgery, radiotherapy, systemic therapy and no treatment) on OS. Covariates included age, race, Charlson comorbidity score (CCI), clinical T stage, biopsy Gleason score, serum prostate specific antigen (PSA), and income. Adjusted Kaplan-Meier estimates were used to visualize the impact of treatment modality on OS.

RESULTS: In men with nonmetastatic ductal PCa, median (IQR) age and PSA were 67 (61-74) years and $6.3(4.3-10.8) \mathrm{ng} / \mathrm{mL}$, respectively. Further, 9.8\% $(\mathrm{n}=195)$ of patients presented with cT3 disease or higher, $3.4 \%(\mathrm{n}=68)$ presented a CCI score $\geq 4$, and $40.6 \%$ (808) presented with a Gleason biopsy score $\geq 4$. Further, 1212 (60.8\%) patients were treated surgically, 406 (20.4\%) with radiotherapy, $102(5.1 \%)$ with systemic therapies, and $273(13.7 \%)$ received no treatment. Multivariable analysis showed that in comparison to men treated surgically, OS was significantly lower for patients receiving radiotherapy (HR 2.6; 95\% CI 1.7-4.0) and systemic therapies (HR 9.1; 95\% CI 5.0-16.5). Adjusted Kaplan-Meier curves are shown in the associated figure.

CONCLUSIONS: Our findings show that in the rare ductal PCa variant, starting treatment with surgery offers more favorable long-term OS outcomes than radiotherapy and systemic therapies. While residual selection bias might persist after adjustment, the rarity of this disease precludes the possibility of a future trial, and the presented data represents the best available level of evidence on this topic. 